http://ejournal.upi.edu/index.php/jaz - e-mail: jurnal.zonasi@gmail.com dan jurnal zonasi@upi.edu doi.org/10.17509/jaz.v2i3.17610

\title{
INTERLOCKING SYSTEM PADA KONSTRUKSI KNOCK DOWN BANGUNAN TRADISIONAL JAWA TAJUG SEBAGAI TEKNOLOGI RESPONSIF GEMPA
}

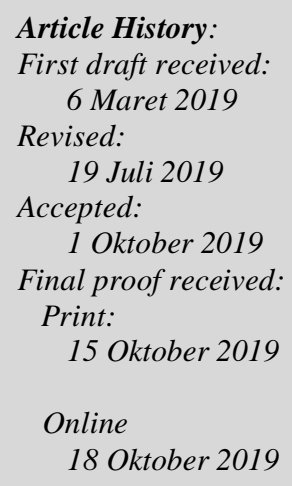

\author{
Nitih Indra Komala Dewi ${ }^{1}$; Sri Novianthi Pratiwi ${ }^{2}$; Mei Nisa Fajria ${ }^{3}$ \\ ${ }^{1}$ Departemen Pendidikan Teknik Arsitektur, Universitas Pendidikan Indonesia \\ Jl. Dr. Setiabudhi No.207, Bandung, Indonesia \\ ${ }^{2}$ Prodi Arsitektur, Universitas Trisakti \\ Jl. Kyai Tapa no. 1 Grogol, Jakarta Barat, Indonesia \\ ${ }^{3}$ Institut Teknologi Bandung \\ Jl. Ganesha Nomor 10, Bandung, Indonesia \\ Email: nitih@upi.edu ; srinovianthi@trisakti.ac.id ; mn.fajria@gmail.com
}

\begin{abstract}
Java Island is located on the ring of fire having active earth plate movements. The movement of the earth plates causes earthquakes with very high intensity. Earthquake factor is a major consideration in the construction of building structure systems. Traditional Javanese buildings have earthquake responsive building structures. The use of knock down timber construction connections is classified as an interlocking system in the form of notch, fulcrum, compressive force, hook and attraction. The system causes flexibility, attenuation, stability, elasticity in the framework of the building resulting in a unity in building systems that are responsive to the earthquakes. This study describes the interlocking system technology found in knock-down timber construction in traditional Java Tajug buildings.
\end{abstract}

Keywords: Knock Down, Interlocking System, Timber Connection System, Traditional Java Tajug Buildings

\begin{abstract}
Abstrak: Pulau Jawa terletak pada jalur ring of fire memiliki pergerakan lempeng aktif. Pergerakan lempeng ini menyebabkan terjadinya gempa dengan intensitas yang sangat tinggi. Faktor gempa menjadi pertimbangan utama dalam pembentukan sistem struktur pada bangunan. Bangunan tradisional Jawa memiliki sistem struktur bangunan yang responsif gempa. Penggunaan sambungan konstruksi kayu knock down diklasifikasikan sebagai sistem koncian atau pengunci (interlocking system) yang berupa takik, tumpu, tekan, kait dan tarik. Sistem tersebut mengakibatkan sifat fleksibilitas, redaman, stabilitas, elastisitas pada rangka bangunan sehingga menjadi satu kesatuan dalam sistem bangunan yang responsif terhadap gempa. Kajian ini mendeskripsikan tentang teknologi sistem pengunci (interlocking system) yang terdapat dalam konstruksi kayu dengan sistem knock down pada bangunan tradisional Jawa tajug.
\end{abstract}

Kata Kunci: Knock Down, Interlocking System, Sistem Sambungan Kayu, Rumah Tradisional Jawa Tajug.

\section{Pendahuluan}

Letak geografis Indonesia dalam ring of fire membentang sepanjang lempeng tektonik teraktif di dunia. Indonesia terletak berada pada tiga lempeng besar di dunia, yaitu lempeng Pasifik, Eurasia, dan IndoAustralia (Noor, 2014)(Permana, Susanti, dan Wijaya, 2019). Wilayah yang berada pada zona ini berkontribusi hampir $90 \%$ kejadian gempa di dunia dan gempa besar banyak terjadi di zona ini. Pulau Jawa terletak pada zona gempa dengan klasifikasi wilayah gempa III dan berada pada jalur sirkum mediteran. Tingkat skala kekuatan gempa di pulau Jawa bagian selatan termasuk dalam wilayah dengan potensi gempa berintensitas tinggi, wilayah Jawa bagian tengah ke arah utara termasuk dalam wilayah dengan potensi gempa berintensitas sedang, sedangkan wilayah Jawa Tengah, Jawa Timur, termasuk dalam wilayah dengan potensi 
gempa berintensitas rendah (BNPB, 2014). Kejadian gempa memiliki resiko yang dapat mengakibatkan korban jiwa dan bangunan merupakan elemen yang paling rentan terhadap resiko terhadap gempa. Tingginya resiko gempa terutama pada tingkat hunian tinggi atau kumpulan bangunan yang rentan terdampak gempa. Disamping itu, Tingginya resiko dan dampak gempa terjadi karena kaidah-kaidah teknik tidak diterapkan dengan baik dalam proses pembangunan, kualitas dan mutu bangunan rendah, penggunaan material atap yang terlalu berat, cacat konstruksi pada bangunan, ketidaktepatan faktor penempatan bangunan, misalnya pada lereng-lerang yang memiliki daya dukung tanah rendah atau tanah yang lembek merupakan faktor yang berkontribusi terhadap tingginya resiko korban jiwa terdampak gempa.

Berdasarkan kajian berbagai sumber sejarah, Arsitektur Tajug telah ada sejak abad ke-delapan, pembangunan rumah tinggal dan bangunan dengan fungsi lainnya di Jawa didirikan oleh penduduk secara tradisi atau turun temurun. Penggunaan perhitungan secara rasional dan pemilihan material alami dalam pembentukan konstruksi sebagai upaya menJawab tantangan alam, yaitu faktor kegempaan. Dalam proses pembangunan, masyarakat pada masa itu melakukan uji coba (trial and error) untuk mendapatkan sistem konstruksi yang paling baik dan sesuai dengan kebutuhan serta responsif terhadap gejala alam, salah satunya terhadap bencana gempa. Sistem konstruksi ini merupakan sistem responsif bangunan terhadap gempa (earthquake responsive building) sebagai bentuk mitigasi gempa. Gempa menjadi pertimbangan utama dalam penemuan sistem struktur bangunan yang baik. Meskipun pada abad ke-delapan belum mengenal dan belum menggunakan teknologi canggih, akan tetapi masyarakat pada masa itu sudah sangat arif dalam menciptakan bentuk bangunan yang unik dan beradaptasi dengan kondisi lingkungan di pulau Jawa yang termasuk pada zona wilayah dengan resiko tinggi terhadap gempa (prihatmaji, 2007)(Rinaldi dan Permana, 2019).

Ketahanan sistem konstruksi bangunan tradisional terhadap gempa dibuktikan ketika pulau Jawa diguncang gempa, kondisi bangunan-bangunan tradisional masih tetap kokoh berdiri dibandingkan dengan bangunan yang didirikan masa kini. Diperkuat dengan beberapa penelitian yang melakukan usaha pembuktian terhadap perilaku bangunan tradisional Jawa terhadap gempa. Hasil penelitian tersebut menunjukkan bahwa struktur rumah tradisional Jawa (Joglo) aman dalam beradaptasi dengan kondisi alam ketika terjadi gempa sedang. Berdasarkan pengujian model struktur yang telah dilakukan Prihatmaji (2007), bahwa rumah tradisional Jawa memiliki struktur inti yang dapat menahan beban lateral akibat gempa, struktur ini didukung oleh fleksibilitas, elastisitas, redaman, daktilitas, stabilitas, serta sifat dan konstruksi kayu yang hiperstatis. Penggunaan sistem tumpuan berupa rol dan atau sendi, sistem sambungan pen berupa alur-lidah, serta adanya konfigurasi antar struktur pada kolom. Sistem tersebut mengakibatkan rumah tradisional Jawa memiliki kestabilan terhadap gempa sekalipun pada frekuensi gempa dengan skala kekuatan gempa tinggi dan akselerasi rendah-tinggi (Prihatmaji, 2007). Penelitian lain mengemukakan potensi knock down memiliki fungsi portable yang dapat dipindahkan secara cepat pasca terjadi gempa (Gunawan, 2017)(Susanti, Komala Dewi, dan Permana, 2018)(Prabawa, Indriani, dan Dewiyanti, 2019).

Sistem responsif terhadap gempa tersebut menjadi menarik untuk dikaji dan diungkap dalam kajian ini secara lebih mendalam berkaitan dengan pengetahuan mengenai sistem konstruksi bangunan tradisional yang merupakan teknologi responsif terhadap gempa, melalui penggunaan sistem knock down dengan sistem pengunci (interlocking system) pada setiap sambungan rangka struktur. Sistem sambungan knock down sebagai bagian dari sistem struktur yang memiliki sifat fleksibel apabila menerima gaya gempa, sistem sambungan yang bersifat tidak kaku dapat merespon dengan baik gaya yang terjadi akibat gempa, sehingga tidak terjadi patah seperti struktur bangunan yang menggunakan beton.

Kajian ini menjelaskan tentang teknologi sistem pengunci (interlocking system) yang terdapat dalam konstruksi knock down yang terdapat pada bangunan tradisional Jawa tajug dan potensi responsifitas terhadap gempa. Teknologi yang responsif terhadap gempa tersebut, sangat terbuka kemungkinan memiliki potensi pengembangan dan penerapan pada masa sekarang. Kajian ini dibatasi pada sistem sambungan kayu yang merupakan interlocking system yang diterapkan pada konstruksi knock down bangunan tradisional Jawa tajug dengan bentuk tajuk pokok. Bangunan tradisional Jawa ini dipilih sebagai objek bahasan karena salah satu bangunan Jawa dengan sistem struktur yang kompleks.

\section{Metode Penelitian}

Metode digunakan dalam kajian ini adalah deskriptif depictive. Menurut Wayne Attoe (1978), deskriptif depictive dalam konteks Arsitektur merupakan salah satu bentuk kritik dalam arsitektur. Depictive digunakan untuk menggambarkan suatu objek dalam arsitektur. Metode ini menyatakan apa yang sesungguhnya terjadi, di dalamnya tidak terdapat pernyataan benar atau salah. Despictive dalam aspek statik memberikan fokus perhatian pada elemen-elemen, terdiri dari: 1) bentuk (form); 2) permukaan (texture); dan 3) bahan (material). Kajian dilakukan pada bangunan masa tunggal yang tidak umum dan terbatas. Metode 
ini seringkali digunakan dengan tujuan untuk menyampaikan pandangan tentang pemahaman objek yang telah dilihatnya sebelum menyampaikan penafsiran terhadap apa yang telah dilihatnya kemudian. Data yang diperoleh melalui kajian literatur mengenai sistem struktur dan konstruksi bangunan tradisional Jawa tajug. Disamping itu, kaji literatur mengenai arsitektur joglo diperlukan untuk menggali data mengenai bangunan tradisional Jawa dan perilakunya terhadap gempa. Pada dasarnya, kedua jenis bangunan tradisional ini, baik tajug maupun joglo memiliki kesamaan dalam sistem struktur dan konstruksinya. Kajian ini bertujuan untuk menggali potensi sistem sambungan kayu pada bangunan tradisional Jawa Tajug yang bersifat responsif terhadap gempa.

\section{Hasil dan Pembahasan}

\subsection{Sejarah dan Tipologi Bangunan Tradisional Jawa Tajug}

Sejarah bangunan tradisional Jawa dipetakan melalui bagan, sebagai berikut:

\begin{tabular}{|c|c|c|c|c|}
\hline $\begin{array}{c}\text { Abad ke-8 } \\
\text { (8th century } A D)\end{array}$ & $\begin{array}{c}\text { Abad ke-10 } \\
(\text { 10th century } A D)\end{array}$ & $\begin{array}{c}\text { Abad ke-15 } \\
(\text { 15th century AD) }\end{array}$ & $\begin{array}{c}\text { Abad ke-18 } \\
\text { (18th century AD) }\end{array}$ & $\begin{array}{c}\text { Sekarang } \\
\text { present }\end{array}$ \\
\hline & Arsitektur Madura, Tajug, Limasan, Kapung \\
\hline $\begin{array}{c}\text { Arsitektur Candi } \\
\text { Jawa Tengah }\end{array}$ & & Joglo Jawa & & \\
\hline & $\begin{array}{c}\text { Arsitektur Candi } \\
\text { Jawa Timur }\end{array}$ & & Arsitektur Kolonial \\
\hline
\end{tabular}

Gambar 1. Sejarah Peradaban Jawa

(sumber: Hindarto, 2011)

Gambar 1 menunjukkan diagram sejarah peradaban Jawa. Berdasarkan bagan tersebut, arsitektur tajug berkembang sejak abad ke-8 (Hindarto, 2011). Berdasarkan perkembangan bentuk, klasifikasi rumah tradisional Jawa diklasifikasikan menjadi 4 (empat) jenis, antara lain Panggangpe, Kampung, Limasan, Joglo. Sedangkan Tajug digunakan untuk tempat-tempat ibadah, tidak dipakai untuk tempat tinggal. Pembagian tersebut sejalan dengan Hamzuri (Prihatmaji, 2007) yang juga mengklasifikasikan beberapa tipe bangunan yang berkembang di wilayah Jawa antara lain, Panggangpe, kampong, limasan, joglo, serta tajug. Berdasarkan klasifikasi tersebut terdapat hirarki kesempurnaan atau keutamaan berdasarkan kompleksitas strukturnya, teknik dalam pengerjaannya, jumlah bahan material bangunan, penggunaan biaya serta tenaga yang diperlukan dalam pembangunannya.

Berdasarkan material yang digunakan, seluruh bangunan tradisional Jawa termasuk tajug menggunakan material yang sama yaitu kayu, dari jenis jati, nangka, maupun glugu. Sedangkan rumah joglo umumnya terbuat dari kayu Jati. Istilah joglo berasal dari bentuk atap yang memiliki filosofis bentuk yaitu sebuah gunung. Awal mulanya, filosofis bentuk gunung tersebut diberi nama atap tajug, tetapi kemudian berkembang menjadi atap joglo/juglo, berasal dari kata tajug loro yang memiliki arti dua tajug atau penggabungan dua tajug (Fajri, 2012). Filosofis gunung sering digunakan dalam kehidupan masyarakat Jawa dalam berbagai bentuk simbol, terutama berkaitan dengan sesuatu yang bersifat sakral karena adanya pengaruh kuat terhadap keyakinan bahwa gunung atau tempat yang tinggi merupakan tempat yang dianggap suci. Sebagian besar bangunan langgar dan masjid menerapkan Arsitektur Tradisional dengan bentuk tajug. Perbedaan antara joglo dan tajug dari segi bentuk, divisualisasikan ke dalam Gambar 2, sebagai berikut: 


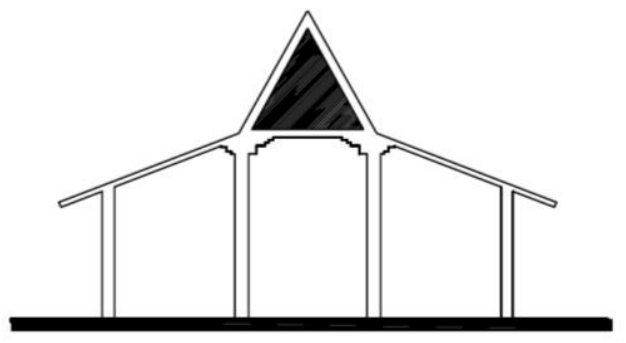

(A)

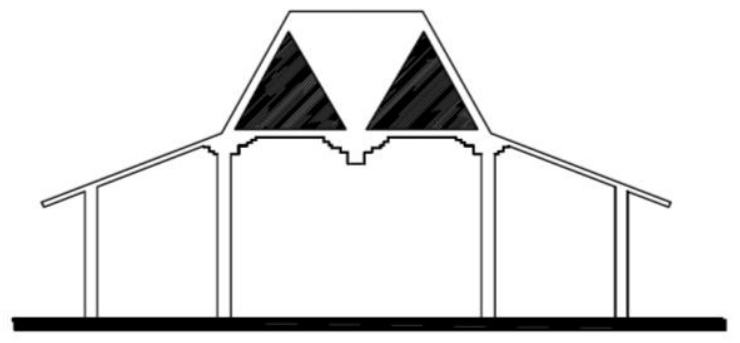

(B)

Gambar 2. Perbedaan Bentuk Bangunan (A) Tajug dan (B) Joglo (Tajug Loro)

(Sumber: Fajri, 2012)

Bentuk (A) merupakan bangunan dengan atap tajug, bentuk (B) merupakan bangunan dengan atap Joglo. Perbedaannya terdapat pada bentuk gunungan, tajug memiliki satu gunungan berbentuk kerucut, sedangkan joglo, gabungan dua gunungan yang membentuk limasan. Tipologi Arsitektur tradisional pada bangunan berbentuk tajug dengan fungsi sebagai langgar atau masjid adalah persegi panjang atau bujur sangkar pada bangunan pokoknya dan terdapat bangunan tambahan berupa emper atau teras. Penggunaan emper berfungsi sebagai tempat tambahan apabila jamaah masjid bertambah banyak dan tidak dapat tertampung lagi pada bangunan utama masjid (Dakung, 1998).

\subsection{Bentuk bagian-bagian bangunan Tajug}

Bentuk bangunan tajug hampir sama dengan bangunan joglo. Perbedaan yang mendasar bangunan tajug berbentuk runcing atau lancip. Filosofi bentuk atap tersebut merupakan lambang dari keesaan dan keabadian Tuhan. Di tengah bangunan ini memiliki 4 (empat) buah tiang yang disebut sebagai saka guru, sedangkan atapnya memiliki 4 (empat) belah sisi (Dakung, 1998). Bangunan tajug pokok digambarkan sebagai berikut:

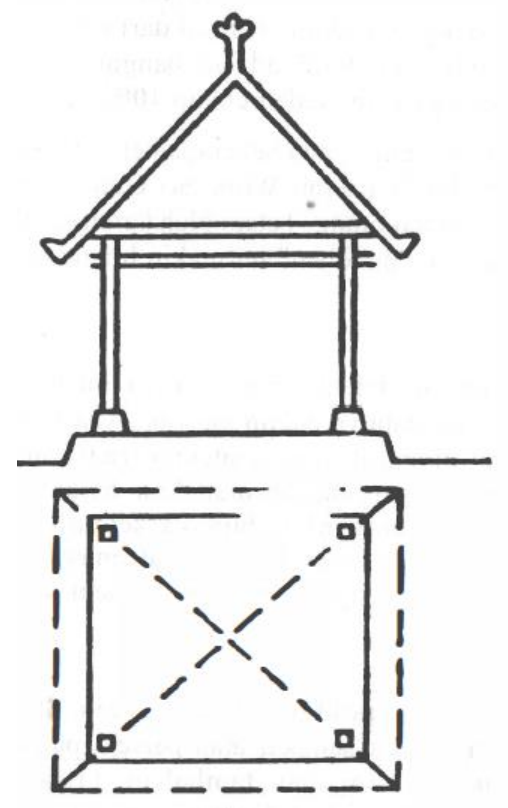

Gambar 3. Bentuk Bangunan Tajug Pokok (Sumber: Dakung, 1998)

Bentuk pokok bangunan tradisional Jawa tajug dengan bentuk denah dasar persegi, terdiri dari 4 (empat) buah saka guru dan 4 (empat) sisi atap. Disamping itu, bangunan tajug memiliki pengembangan variasi lainnya. Variasi bangunan tajug dijelaskan melalui tabel 1 sebagai berikut: 


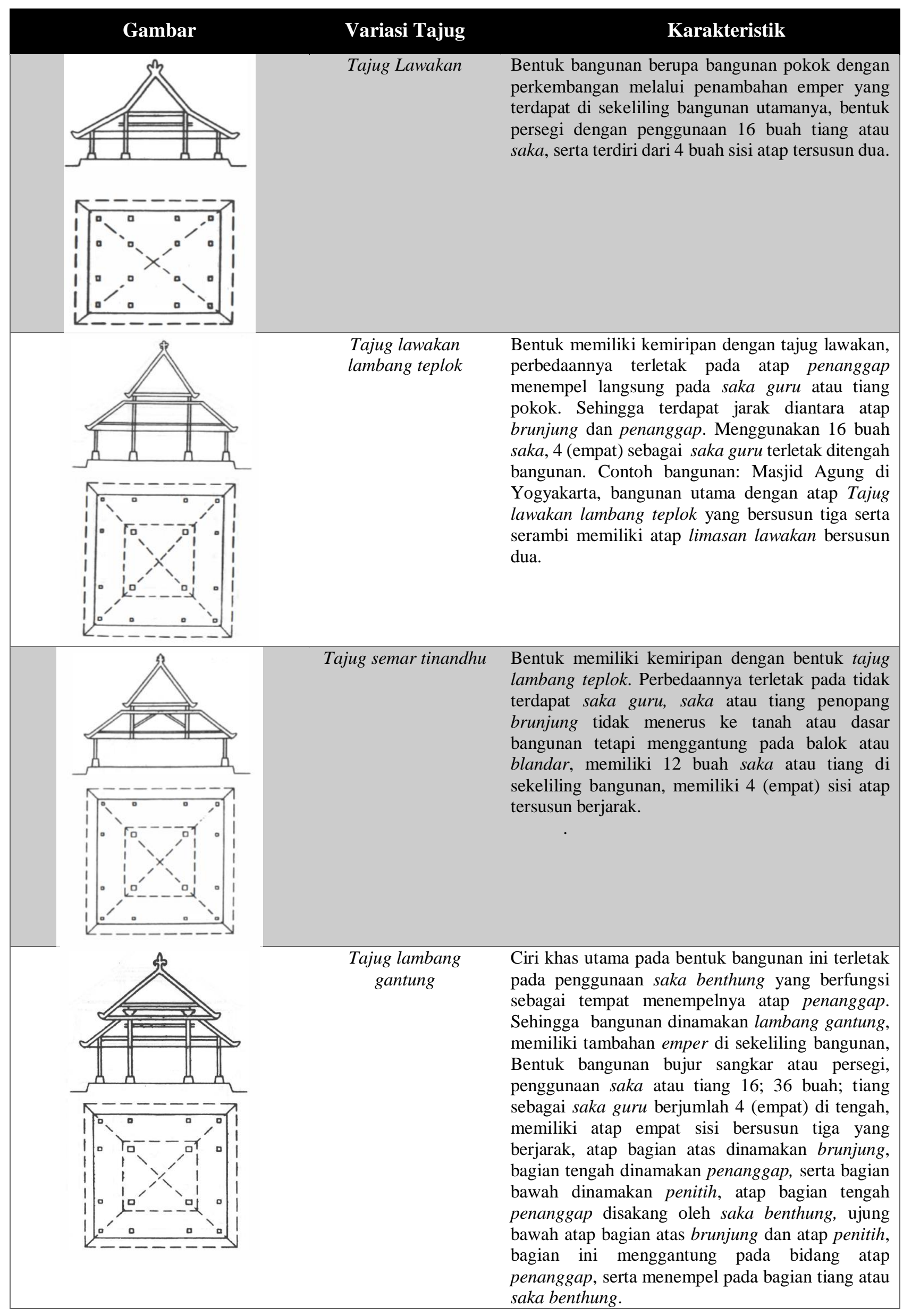




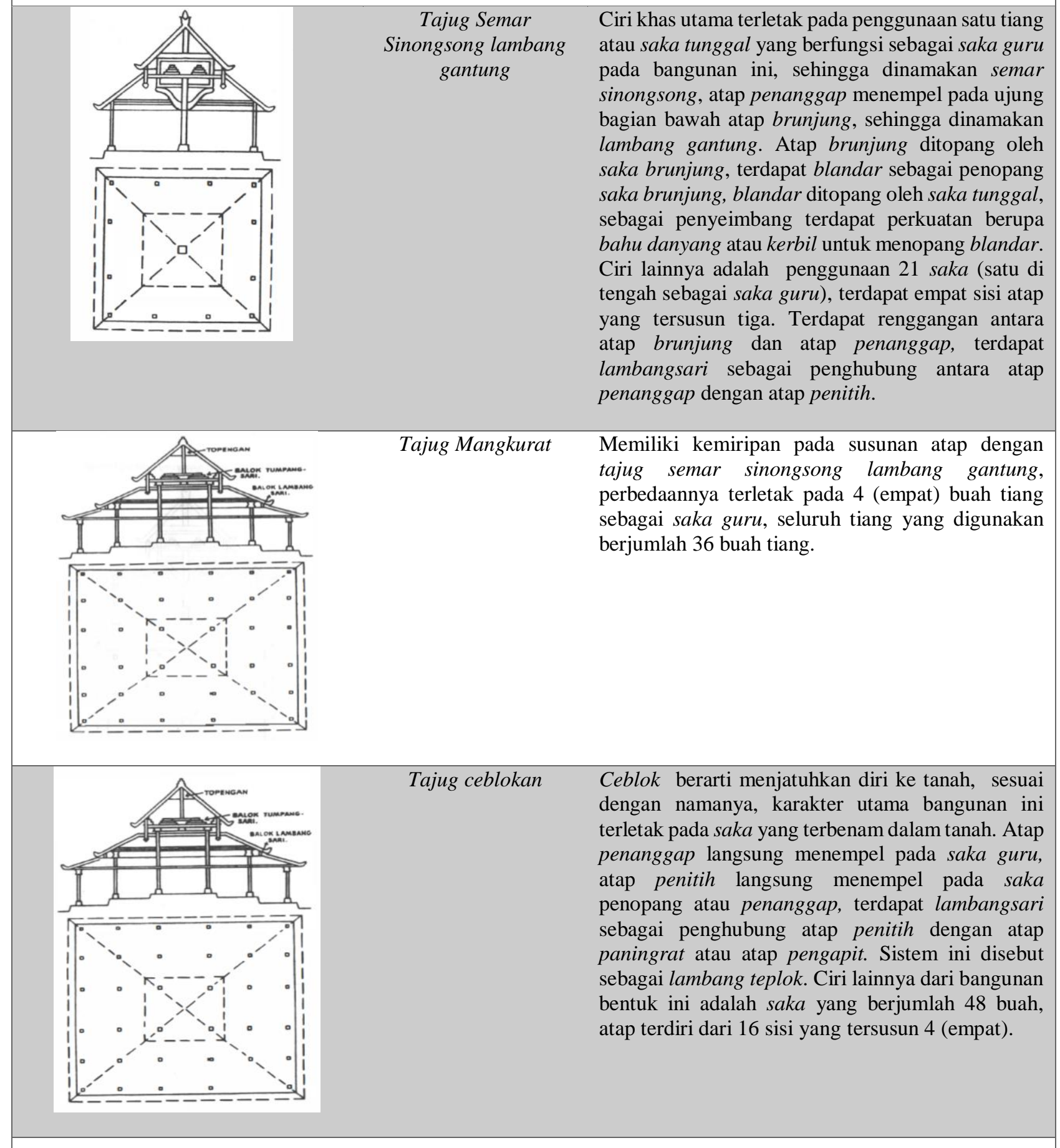

(Sumber: Dakung, 1998) 


\subsection{Sistem Struktural Bangunan Tahan Gempa}

Berdasarkan teori yang dikemukakan Mangunwijaya (Prihatmaji, 2007), getaran yang dihasilkan saat terjadi gempa bumi, terdiri dari: 1) gelombang primary yang memiliki getaran dan berhimpitan searah dengan arah rambatan gelombang; 2) gelombang secondary, bergerak ke arah tegak lurus dengan arah rambatan, serta 3) gelombang large, yaitu gelombang yang berjalan pada permukaan tanah. Getaran gempa tersebut menghasilkan gaya inersia akan berpengaruh terhadap bangunan. Gaya inersia saat terjadi gempa merupakan gaya yang muncul akibat adanya percepatan gempa terhadap massa bangunan yang terdapat di atas permukaan tanah, gaya ini menyebabkan bangunan bergetar mengikuti arah getaran tanah, dan mengalami gaya guling yang disebabkan oleh gaya berulang dan berbolak-balik. Akibatnya, bangunan dapat menekuk pada bagian bawah serta menghasilkan gaya torsi, disebabkan oleh perbedaan posisi pusat kekakuan massa terhadap pusat gempa. Gaya-gaya ini dapat mengakibatkan bangunan berputar terhadap sumbu x (Subekti, 1998).

Bangunan kayu memberikan reaksi terhadap gempa, melalui sifat: 1) fleksibilitas, yaitu kekakuan dan keliatan dari unsur atau sambungannya yang membentuk keliatan; 2) redaman \& stabilitas, kemampuan friction \& pegas sebagai bentuk penyerapan getaran untuk memberikan perlawanan terhadap gaya inersia; 3 ) elastisitas \& daktilitas, merupakan kemampuan bangunan melakukan deformasi plastis tanpa runtuh (Wangsadinata, 1988), struktur yang dirancang harus memiliki tingkat daktilitas tinggi, sehingga saat terjadi gempa, kuat struktur memiliki kemampuan untuk deformasi tanpa mengakibatkan dampak keruntuhan bangunan (Rekayasa Gempa, 2019); dan 4) sifat hiperstatis yang dihasilkan oleh unsur balok pembentuk sendi plastis (Prihatmaji, 2007).

Persyaratan yang harus dipenuhi pada struktur bangunan tahan gempa berdasarkan Applied Technology Council (Rekayasa Gempa, 2019), di antaranya:

1. Keutuhan struktur bangunan, saat terjadi gempa ringan struktur bangunan tetap dalam kondisi utuh serta tidak mengalami kerusakan.

2. Toleransi kerusakan komponen non-stuktural, saat terjadi gempa sedang, komponen non-struktural yang merupakan bagian dari struktur bangunan masih ditoleransi mengalami kerusakan, tetapi komponen struktural tetap dalam kondisi utuh.

3. Toleransi kerusakan komponen struktural dan non-struktural, saat terjadi gempa kuat, komponen nonstruktural serta komponen struktural yang berasal dari sistem struktur masih diberikan toleransi kerusakan, akan tetapi struktur bangunan keseluruhan tetap dalam kondisi utuh dan tidak boleh runtuh. Adanya toleransi kerusakan pada struktur bangunan, akan tetapi sebisa mungkin mampu menghindari terjadinya korban jiwa akibat dampak gempa.

\subsection{Kaidah Tahan Gempa pada Bangunan}

Gempa menghasilkan beban dinamik yang terjadi dengan arah bolak-balik, tidak terus menerus bekerja pada bagian struktur bangunan, atau dengan kata lain beban gempa pada bangunan merupakan beban yang bekerja pada struktur bangunan yang bersifat sementara, sehingga diperlukan perencanaan yang baik pada struktur bangunan, terkait dengan daktilitas, sifat daktail pada struktur bangunan menyebabkan bangunan mampu berdeformasi plastis, mekanisme deformasi plastis ini terjadi melalui terbentuknya sendi-sendi plastis dan terkontrol, sehingga ketika terjadi gempa yang kuat, bangunan tidak mengalami kerusakan pada struktur bangunan dan bangunan tetap kokoh berdiri dan tidak runtuh (Rekayasa Gempa, 2019).

Perancangan bangunan tahan gempa memiliki kaidah-kaidah yang harus dipenuhi, antara lain; 1)bentuk denah bangunan sederhana dan simetris, 2) Keteraturan susunan dan bidang simetris dinding-dinding partisi dalam bangunan, 3) Keterikatan antara bidang dinding dengan dinding lain atau bidang dinding terikat dengan kolom, 4) Penggunaan material ringan pada konstruksi atap, 5) Kekuatan rangka kuda-kuda atap bertumpu pada dinding maupun kolom sebagai tumpuan, 6) Letak pondasi pada tanah padat dan rata, 7) Terdapat balok pengikat (penghubung) atara kolom atau dinding, 8) terdapat balok sebagai pengkaku tersambung dengan bidang dinding dan tiang, 9) Terdapat perkuatan pada pertemuan kolom, balok cincin, dan lainnya 10) adanya pengait antara dinding dengan tiang. Faktor-faktor tersebut sejalan dengan Gutierrez, terdapat 4 (empat) kaidah dalam perancangan bangunan tahan gempa, yaitu : 1) sederhana dan simetris pada denah atau bentuk bangunan, 2) Penggunaan material ringan, 3) rigid dan fleksibel pada sistem sambungan, dan 4) kesatuan sistem struktur dan konstruksi, antara pada struktur atap, dinding, hingga pondasi (Triyadi, 2010). 


\subsection{Perilaku Bangunan Tradisional Jawa terhadap Gempa}

Perilaku bangunan tradisional Jawa terhadap gempa, antara lain: 1) Bentuk bangunan memiliki nilai keamanan tinggi. Hal ini diperoleh berdasarkan hitungan matematis dan logika mekanika terhadap bentuk rumah Jawa; 2) Kestabilan bangunan terhadap gaya yang terjadi akibat gempa, tetapi sifat sambungan pada bangunan tradisional Jawa memiliki kelemahan terhadap beban lateral (Frick, 1997); 3) Kekuatan struktur bangunan terletak pada struktur yang disebut rong-rongan dan sifat kaku dihasilkan dari struktur rangka ruang, kombinasi pada sistem sstruktur ini merupakan struktur core in frame (Siddiq, 2002), 4) struktur rumah tradisional Jawa Joglo dapat menahan getaran gempa pada zona III melalui sifat daktilitas saka guru proporsi bentuk struktur bangunan, serta kualitas konstruksi pada sambungan kayunya (Prihatmaji, 2007). Gambar berikut menjelaskan bagaimana penyaluran aksi gaya gempa pada rumah tradisional Jawa.
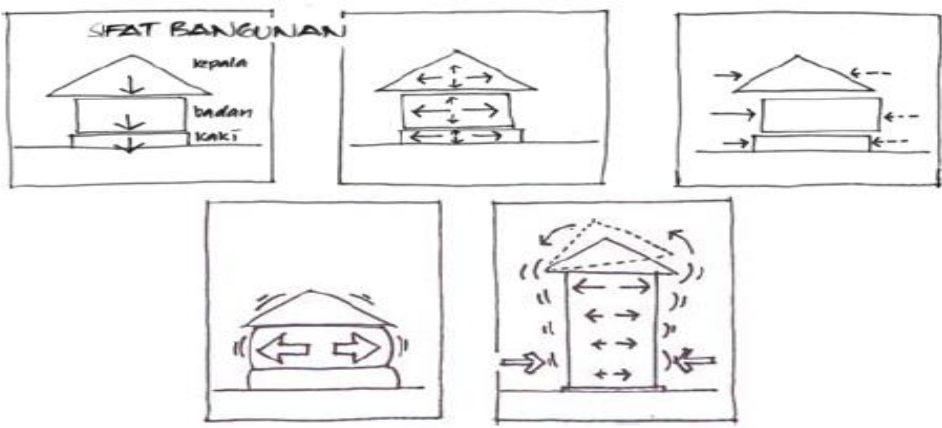

Gambar 4. Aksi Gaya Gempa yang terjadi pada Rumah Tradisonal Jawa (Sumber: Prihatmaji, 2007)

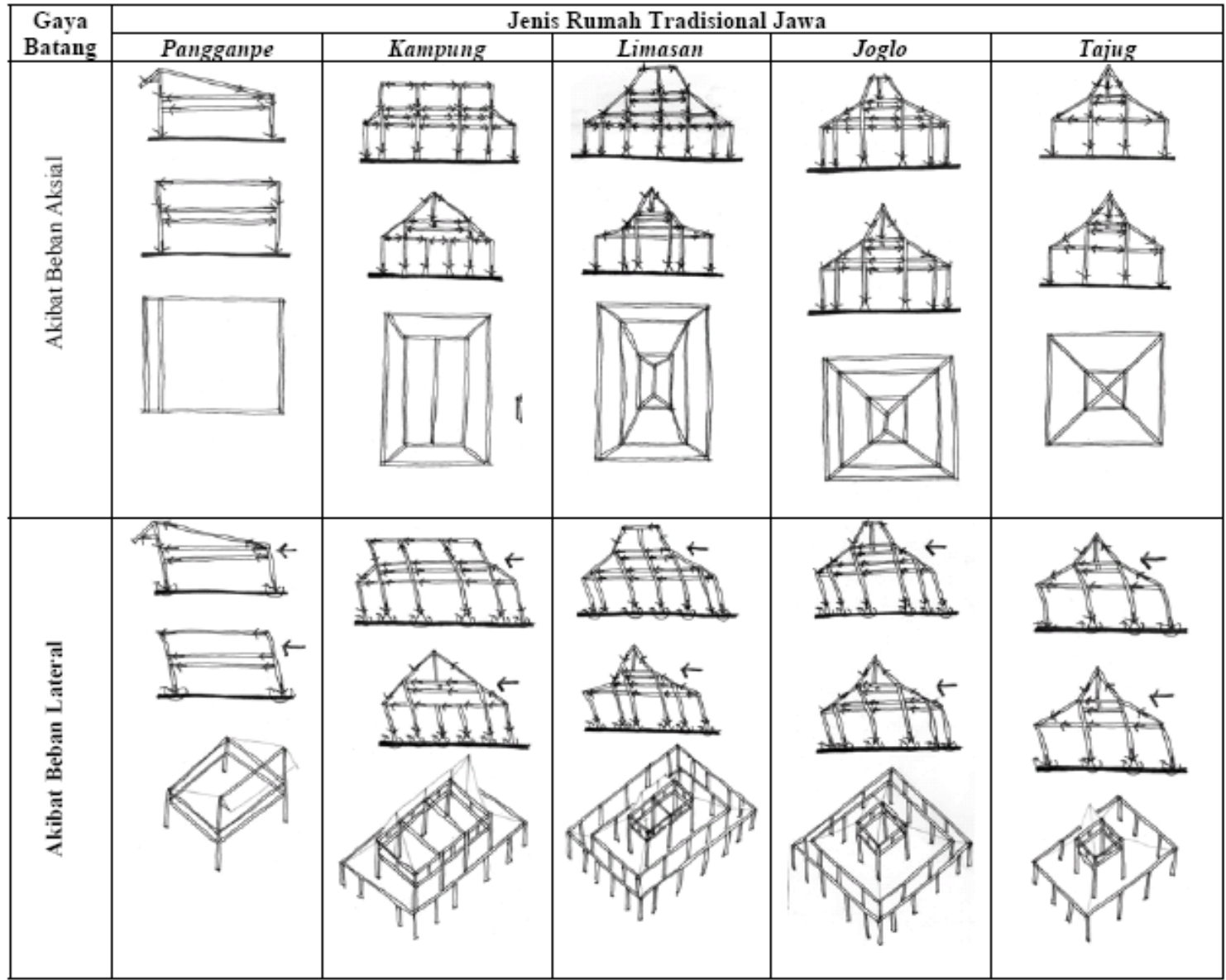

Gambar 5. Reaksi terhadap Gaya Lateral dan Beban Sendiri pada Rumah Tradisional Jawa

(Sumber: Prihatmaji, 2007) 
Berdasarkan gambar 5 memperlihatkan gambaran bahwa sambungan struktur bangunan tradisional jawa merupakan titik kritis pada bangunan tahan gempa di sambungan. Pada bangunan tradisional Joglo, umpak-saka guru merupakan titik sambungan struktur memiliki pertemuan sambungan yang bersifat sendi, sedangkan sambungan yang bersifat jepit terdapat pada sambungan antara saka guru-blandar-sunduk-atap. Sifat sendi dan jepit merupakan perpaduan sambungan yang mampu merespon gaya yang dihasilkan saat terjadi gempa. Adanya sambungan yang bersifat jepit pada blandar berfungsi sebagai penstabil bangunan saat terjadi gempa, seperti halnya pendulum. Sedangkan sambungan sendi pada bagian umpak, merupakan peredam getaran gempa menuju ke saka guru (base isolation). Bekerjanya sifat jepit pada blandar dan sendi pada umpak secara bersamaan pada saat terjad gempa, menghasilkan friksi yang berfungsi sebagai peredam getaran (Prihatmaji, 2007). Berdasarkan hubungan antara arsitektur dan budaya, rumah tradisional Jawa merupakan bentuk strategi adaptasi manusia dalam menciptakan struktur bangunan yang mampu bertahan terhadap alam (gempa). Bentuk adaptasi ini diaplikasikan melalui adanya rekayasa struktur dan konstruksi melalui sistem tumpuan dan sambungan, serta pemilihan material lokal berupa kayu, bambu,dan batu.

Rumah tadisional Jawa tidak lagi dipandang hanya sebagai perwujudan ekspresi fisik dari sebuah fasad dan memperlihatkan konstruksi, tetapi merupakan bentuk penyesuaian terhadap alam nyata, yang di dalamnya terdapat iklim dan topografi sebagai definisi berdasarkan filosofi mikrokosmos (buana alit), serta alam maya dalam makrokosmos (buana ageng). Faktor gempa secara tidak langsung memberikan peran terbentuknya sistem struktur, visual serta bentuk arsitektur. Ketiga faktor tersebut saling berhubungan pada pembentukan bangunan tradisonal Jawa dalam segi detail elemen struktur, konfigurasi bentuk denah serta proporsi bangunan. Tampilan visual dari detail struktur yang terekspos, sekaligus memberikan kesan estetis dan keindahan secara visual baik dalam interior maupun melalui eksterior bangunan, memperlihatkan bahwa bangunan tradisional Jawa memiliki keselarasan antara keamanan dari struktur yang tahan gempa juga secara visual menciptakan bangunan yang memiliki nilai selaras dengan budayanya (Prihatmaji, 2007)(Setiohastorahmanto, Soetomo, dan Sardjono, 2018).

\subsection{Komponen Knock Down pada bangunan Tradisional Jawa Tajug}

Bagian utama bangunan tradisional tajug, terdiri dari: 1)Bagian bawah, terdiri dari pondasi (bebatur) hingga umpak. Tiang-tiang utama atau saka guru serta tiang lainnya diletakkan di atas umpak sebagai basenya. Fungsi umpak atau batu kapur dengan tujuan menahan tiang sehingga tidak masuk/amblas ke dalam bebatur serta fungsi kapur adalah sebagai upaya pencegahan resapan air tanah melalui bagian bawah tiang; 2) Bagian tengah, terdiri dari tiang dan konstruksi pendukung atap.Tiang utama atau saka ditegakkan di atas umpak. Sebelum dipasang, tiang ini diberi penyiku (sunduk) yang berfungsi sebagai penyangga atau stabilisator, 3) Bagian atas atau bagian kepala, bangunan tradisional Jawa tajug terdiri dari saka guru, ujung atas hingga bagian atap. Sistem konstruksi bagian ini merupakan bagian yang paling rumit. Bagian-bagian bangunan tradisional Jawa Tajug pada gambar berikut:

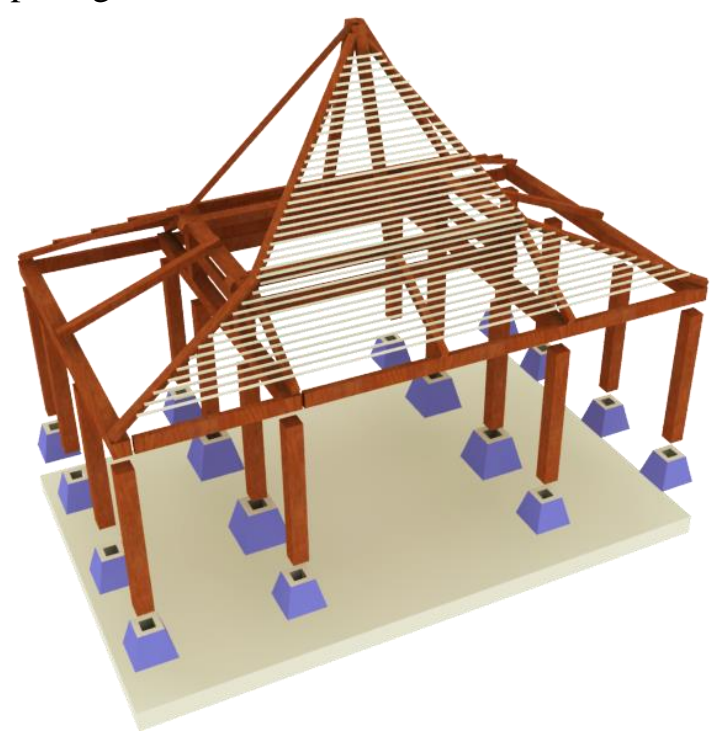

Gambar 6. Rangka Bangunan Tradisional Jawa Tajug (Sumber: Penulis, 2019) 
Pada bagian atas/ kepala, terdapat dua teknik penyusunan balok, antara lain: 1) Teknik tumpang, merupakan teknik sisi panjang sebagai tumpuan balok bagian dalamnya, 2) Teknik adu bibir, yaitu sisi balok yang ditopang dan menopang saling bertemu pada salah satu sisinya.

Inti struktur bangunan tradisional Jawa tajug pokok terletak pada 4 (empat) kolom atau saka yang menjadi inti bangunannya, konfigurasi kolom ini dikenal sebagai saka guru. Saka guru terletak pada bagian atas bangunan dengan detail terumit. Pada keempat sudut bagian atasnya memiliki sambungan knock down yang memiliki sistem pengunci (interlocking system). Keempat pilar atau saka guru digambarkan sebagai berikut:



Gambar 7. Rangka Saka guru (Tiang Utama) Bangunan Tradisional Jawa Tajug

(Sumber: Penulis, 2019)

Pada bangunan tradisional Jawa tajug, umumnya memiliki dari 4 (empat) tiang atau saka di tengah bangunan. Pada setiap sudut-sudut seperti ditunjukkan pada gambar bagian A maupun B, keempat sudut tersebut memiliki detail yang sama yang memiliki sistem sistem pengunci (interlocking system). Detail sambungan dengan interlocking system ini digambarkan pada gambar 8 sebagai berikut:

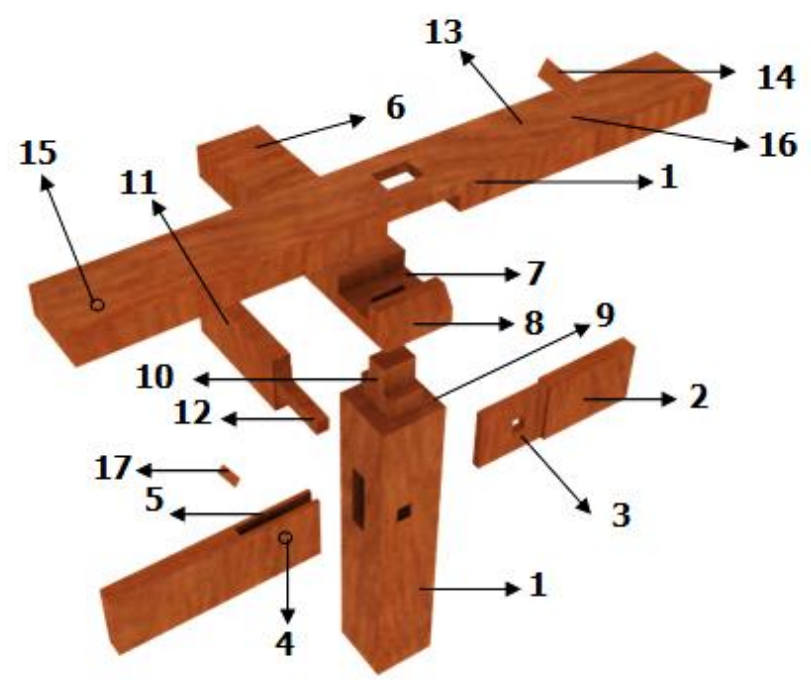

Gambar 8. Detail Sambungan A\&B Rangka Saka guru (Tiang Utama) Bangunan Tradisional Jawa "Tajuk"

(Sumber: Penulis, 2019)

Gambar 8 menunjukkan komponen-komponen sambungan kayu yang memiliki sistem pengunci, Berdasarkan gambar, komponen knock down pada sambungan kayu saka guru diuraikan, sebagai berikut:

1. Saka guru 
2. Sunduk

3. Purus jabung (bagian tengah dari purus sanduk yang masuk pada saka guru )

4. Topong ( penyambung sunduk dan menghubungkan saka guru dengan saka goco)

5. Cangkem boyo (lubang penyambung yang dimasuki purus jabang)

6. Pangerat

7. Keplok

8. Gimabal

9. Genukan

10. Purus patok

11. Kili

12. Purus lanangan

13. Blandar

14. Petek (pengapit empyak pada blandar)

15. Leng kumbang (lubang menacapkan petek)

16. Leng kumbang (untuk memasukan pengunci sambungan sunduk dan topong)

17. Jalak (kayu alat pengunci sambungan topong dan sunduk dan dimasukan pada leng kumbang)

Pada detail sambungan terdapat catokan, teknik catokan ini merupakan sendi pada tumpang. Catokan yang berada paling atas pada bagian penanggap/penitih yang memiliki pengangkur diberi pengunci, dinamakan emprit gantil. Pengunci emprit gantil ini banyak terdapat pada bagian tumpang yang terletak paling atas di-peros atau diberi sisi miring berdasarkan dengan miringnya atap. Catokan dideskripsikan pada gambar berikut:

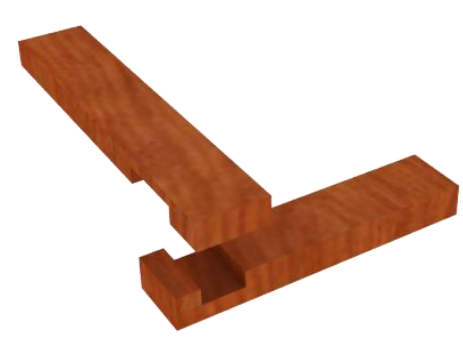

(A)

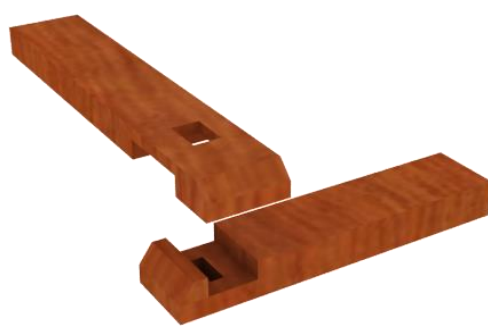

(B)

Gambar 9. Sistem Catokan pada Sendi Sambungan Kayu

Bangunan Tradisional Jawa Tajug

(Sumber: Penulis, 2019)

Gambar 9 (A) menunjukkan catokan pada tumpang tanpa pengunci dan tidak di-peros, gambar 9 (B) menunjukkan catokan yang telah di-peros sesuai dengan kemiringan atap. Kedua teknik catokan ini diuraikan sebagai berikut:

\section{A. Catokan pada tumpang}

Catokan pada tumpang sebagian besar tidak menggunakan pengunci sehingga bagian tengah sambungan catokan tidak berlubang. Meskipun tidak adanya pengunci, catokan ditindih tumpang di bagian atasnya, sedangkan bagian atas tumpang ditindih penanggap dan penangkur yang diberi kunci (togog jalak) dan ditambah berat beban atap, sehingga catokan memiliki kekuatan terhadap gaya geser.

\section{B. Catokan pada penanggap dan penangkur}

Adanya sistem pengunci pada jenis catokan yang terletak pada penanggap dan penangkur. Pengunci ini dinamakan emprit gantil, pada bagian purus pengunci diberi tonjolan ke atas yang berfungsi sebagai penahan terjadinya pergeseran dua buah balok yang berada dibagian atasnya akibat tumpuan iga-iga, dudur, dan $u s u k$ yang memberikan gaya tekan ke samping. Kestabilan atap tertumpu pada kekuatan bagian ini, yaitu balok penanggap dan penangkur. Daya tahan bagian ini juga ditentukan oleh kekuatan rangkaian balok-balok. Gaya berat bagian atap atas ini ditopang oleh tiang-tiang yang selanjutnya disalurkan ke pondasi.

Pada bagian bawah, bagian tengah, dan bagian atas bangunan tradisonal Jawa tajug memiliki $\underline{\text { sambungan-sambungan sendi pada setiap bagian atas yang terintegrasi dengan baik. Sambungan sendi catokan }}$ 
ini merupakan sambungan sendi utama pada sistem knock down bangunan tradisional Jawa tajug. Sistem pengunci yang terdapat pada catokan berfungsi sebagai perkuatan pada sistem knock down. catokan ini mampu memberikan daktilitas pada sambungan sistem knock down sehingga pada bagian sambungan masih dapat bergerak, pada saat terjadi gaya yang diakibatkan oleh gempa maupun gaya lateral hany a membuat saka guru bergoyang. Sedangkan pada bagian bawah, adanya sifat sendi pada umpak mampu mengurangi getaran gempa yang mengenai saka guru (base isolation) dan adanya sifat jepit pada balok blandar menjadikan atap bergerak seperti sistem pendulum/ bandul yang berfungsi sebagai penstabil bangunan (Prihatmaji, 2007). Penggunaan material kayu dan atap sirap juga mendukung sistem struktur knock down pada bangunan tradisional Jawa tajug, menjadikan beban bangunan relatif ringan sehingga mengurangi potensi roboh pada saat terjadinya gempa.

Pada konstruksi knock down ini penggunaan sistem tersebut diklasifikasikan sebagai sistem pengunci atau koncian (interlocking system) berupa takik, tumpu, tekan, kait dan tarik(Siswanto, 2004). Sistem ini membuat konstruksi bangunan tradisional Jawa tajug tahan terhadap gempa. Penggunaan sistem pen dan pasak pada sambungan yang terintegrasi dengan masing-masing komponen struktur bangunan memberikan keuntungan pada bangunan apabila terjadi gempa, antar komponen bangunan masih tetap terikat walaupun terjadi goncangan akibat gempa. Gambar 10 berikut ini merupakan sistem penyaluran gaya pada bangunan tradisional tajug:

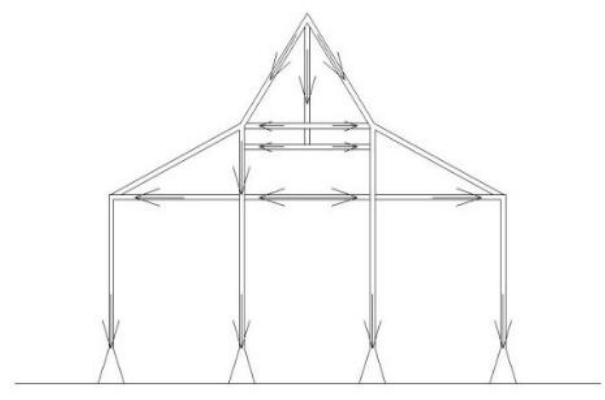

Gambar 10. Penyaluran Gaya pada Bangunan Tradisional Jawa Tajug

(Sumber: Penulis, 2019)

Berdasarkan gambar 10, penyaluran beban pada bangunan tradisional tajug, melalui: 1) bagian atas bangunan, beban atap disalurkan melalui balok yang disebut blandar, 2) bagian tengah bangunan, beban yang diperoleh dari atap disalurkan melalui kolom-kolom yang disebut dengan saka, 3) bagian bawah bangunan, beban yang diperoleh dari tiang atau kolom-kolom disalurkan ke dalam pondasi yang disebut dengan umpak, yang akhirnya disalurkan ke dalam tanah. Konstruksi tiang hingga atap menggunakan material kayu. Penggunaan material kayu dalam struktur bangunan menjadi faktor penentu ketahanan bangunan terhadap gempa. hal ini sejalan dengan teori yang dikemukakan oleh wangsadinata (1988) bahwa Bangunan kayu memberikan reaksi terhadap gempa melalui sifat fleksibilitas (kekakuan dan keliatan), redaman \& stabilitas, elastisitas \& duktilitas. Inti dari kekuatan konstruksi kayu pada bangunan tradisional Jawa Tajug terletak pada sambungan pada bagian atap di atas saka guru, pada sambungan ini terdapat catokan merupakan sambungan sendi utama pada sistem knock down bangunan tradisional Jawa tajug. Sistem ini dinamakan pengonci atau interlocking system. Sambungan kayu ini merupakan sendi plastis yang bersifat hiperstatis (Prihatmaji, 2007).

\section{Kesimpulan}

Sistem konstruksi bangunan tradisional Jawa tajug merupakan teknologi responsif terhadap gempa. sistem struktur dan sambungan yang menggunakan sistem knock down. Pada sambungan rangka struktur kayunya memiliki sistem pengunci (interlocking system). Sistem struktur kayu pada bangunan tradisional Jawa tajug didukung oleh fleksibilitas, elastisitas, stabilitas, redaman, daktilitas, sifat hiperstatis kayu dan konstruksi. Sistem tumpuan memiliki sifat sendi dan atau rol, sistem sambungan lidah alur, serta konfigurasi struktur kolom. Sistem tersebut menunjukkan bahwa bangunan tradisional Jawa memiliki kestabilan terhadap gempa pada frekuensi gempa yang tinggi dan akselerasi rendah-tinggi. Faktor gempa merupakan faktor terpenting dalam pembentukan sistem struktur yang mampu bertahan pada kondisi gempa. Dalam proses menemukan sistem struktur yang memiliki kemampuan beradaptasi terhadap gempa, bangunan tradisional Jawa terbentuk melalui upaya percobaan (trial and error) dalam menghasilkan sistem konstruksi yang paling baik, sesuai dengan kebutuhan akan keamanan dan keselamatan serta responsif terhadap gejala alam berupa gempa. Sistem konstruksi ini merupakan sistem responsif bangunan terhadap gempa (earthquake responsive building) sebagai upaya mitigasi terhadap bencana gempa. 


\section{Referensi}

Attoe, Wayne R. J. (1985). Architectural criticism. Chichester; New York: Wiley.

Badan Nasional Penanggulangan Bencana (BNPB). (2014). Rencana Nasional Penanggulangan Bencana 2015-2019. https://bnpb.go.id/uploads/24/buku-renas-pb.pdf

Dakung, S. (1998). Arsitektur Tradisional Daerah Istimewa Yogyakarta. Departemen Pendidikan dan Kebudayaan.

Fajri, Achmad Junal. (2012). Mengulas Sistem Struktur Joglo Dan Arti Yang Terkandung di dalamnya. http://achmad-jf.blogspot.com/2012/06/mengulas-sistem-struktur-joglo-dan-arti.html. Diakses: 1 Mei 2019.

Frick, Heinz.(1997). Pola Struktural dan Teknik Bangunan di Indonesia (Suatu Pendekatan Arsitektur Indonesia melalaui Pattern Language secara Konstruktif dengan contoh Arsitektur Jawa Tengah), Penerbit Kanisius, Yogyakarta.

Frick, Heinz dan Purwanto, LMF. (1998). Sistem Bentuk Struktur Bangunan (Dasar-dasar Konstruksi dalam Arsitektur), Penerbit Kanisius, Yogyakarta.

Glasser, D.E. (1976). Structural Considerations, in Snyder, James C and Antony J Catnese (Eds), Introduction to Architecture (pp. 268 - 272), Mac Graw-Hill, New York.

Gunawan, Y., Enggarsari, W. dan Putra W, Rafii (2017). Tektonika Arsitektur Joglo. Laporan Penelitian. Lembaga Penelitian dan Pengabdian kepada Masyarakat Universitas Katolik Parahyangan.

Hamzuri. (1982). Rumah Tradisonal Jawa. Proyek Pengembangan Permuseuman DKI Jakarta, Departemen Pendidikan dan Kebudayaan, Jakarta.

Hindarto, Probo. (2011). Arsitektur Tradisional Jawa (Dan Nusantara) Sebagai Bagian Dari Peradaban Dunia. www. Astudioarchitect.com. Diakses: 10 Mei 2019.

Http://www.ristek.go.id / Sistem Struktural Bangunan Tahan Gempa. Diakses: 10 Mei 2019.

Mudjijono WP, Zain et al. (1992). Arsitektur Tradisional Daerah Jawa Timur. Departemen Pendidikan dan Kebudayaan. Jakarta.

Noor, Djauhari. (2014). Tektonik Lempeng, https://www.academia.edu/6464227/Tektonik_Lempeng.

Permana, A. Y., Susanti, I., dan Wijaya, K. (2019). Kerentanan Bahaya Kebakaran di Kawasan Kampung Kota. Kasus: Kawasan Balubur Tamansari Kota Bandung. Jurnal Arsitektur ZONASI, 2(1), 32. https://doi.org/10.17509/jaz.v2i1.15208

Prabawa, M. S., Indriani, W., dan Dewiyanti, H. (2019). Mitigasi Spasial terhadap Bencana Sosial di Permukiman Johar Baru, Jakarta Pusat. Jurnal Arsitektur ZONASI, 2(1), 46. https://doi.org/10.17509/jaz.v2i1.15062

Rinaldi, I. R., dan Permana, A. Y. (2019). Tingkat Kerentanan Bencana Pada Sekolah. Jurnal Arsitektur Zonasi, 2(1), 12-24. https://doi.org/10.17509/jaz.v2i1.14744

Setiohastorahmanto, P., Soetomo, S., dan Sardjono, A. B. (2018). Ruang Andangan Arsitektur Limasan Sebagai Wadah Tradisi Kalang (Etnografi Demang Kalang (sub etnis Jawa). Jurnal Arsitektur ZONASI, 1(2), 63. https://doi.org/10.17509/jaz.v1i2.12216

Siddiq Suwandojo. (2001). Beberapa Tinjauan Aspek Bahan, Konstruksi dan Struktur Bangunan Tradidonal Indonesia (catatan kuliah), Magister Arsitektur, ITB.

Siswanto, Ari . (2004). The Study of Knock Down Timber Construction House Based on the Concept of South Sumatra Timber House Structure. J. Ilmu \& Teknologi Kayu Tropis Vol. 2 No.2. 2004.

Subekti, Bambang. (1998). Upaya Mengurangi Resiko Kerusakan Akibat Gaya lateral pada Bangunan Kolonial Belanda di Bandung,Tesis Program Magister Arsitektur ITB, Bandung.

Susanti, I. S., Komala Dewi, N. I., \& Permana, A. Y. (2018). Tatanan Teritorial dalam Proses Transformasi Hunian. Jurnal Arsitektur ZONASI, 1(1), 27. https://doi.org/10.17509/jaz.v1i1.11542

Triyadi, S., Sudrajat, I., dan Harapan, Andi. (2010). Kearifan lokal pada bangunan rumah vernakular di Bengkulu dalam merespon gempa, Studi kasus: rumah vernakular di desa duku ulu

Wangsadinata, W. (1988). Pengaruh Gempa Terhadap Perancangan Arsitektur Bangunan. Makalah seminar Peranan Arsitektur dan Struktur dalam Perencanaan Bangunan Tinggi), FTSP Universitas Trisakti.

Prihatmaji, Yulianto P. (2007). Perilaku Rumah Tradisional Jawa "Joglo" Terhadap Gempa. Jurusan Arsitektur Universitas Islam Indonesia Yogyakarta. Jurnal Dimensi Teknik Arsitektur Vol. 35, No. 1, Juli 2007: $1-12$.

Yunus, A. (1985). Arsitektur Tradisional Daerah Jawa Tengah. Departemen Pendidikan dan Kebudayaan, Direktorat jendral kebudayaan, Direktorat sejarah dan nilai tradisional. Proyek inventarisasi dan dokumentasi, kebudayaan daerah jawa Tengah 1981 - 1982. 